\title{
The Roles of Government Agency in Assisting CSR Project for Community Development: Analysis from the Recipients Perspectives
}

\author{
Sarmila M. S. ${ }^{1}$, Zaimah R. ${ }^{1}$, N. Lyndon ${ }^{1}$, Azima A. M. ${ }^{1}$, Suhana $\operatorname{Saad}^{1} \&$ S. Selvadurai ${ }^{1}$ \\ ${ }^{1}$ Center of Social Development and Environmental Studies, Social Science and Humanities Faculty, Universiti \\ Kebangsaan Malaysia, Bangi, Malaysia \\ Correspondence: Sarmila M. S., Center of Social Development and Environmental Studies, Social Science and \\ Humanities Faculty, Universiti Kebangsaan Malaysia, 43600 Bangi, Malaysia. E-mail: sarmila@ukm.my
}

\author{
Received: February 12, 2013 Accepted: March 29, 2013 Online Published: April 25, 2013 \\ doi:10.5539/ass.v9n8p17 URL: http://dx.doi.org/10.5539/ass.v9n8p17
}

\begin{abstract}
Corporate Social responsibility (CSR) initiatives by the corporations are playing increasingly significant role in the effort of contributing to community development particularly in the developing country. The international prominence of the initiatives in this area can be traced to the objectives of Millenium Development Goals (MDGs) that established corporations as partners of development. However, realizing the corporate sectors constraints in playing the roles as agents of development, the CSR initiatives need to be implemented with the involvement of the government agency to assist community development. This paper will explore the roles played by government agency in CSR project through a case study of successful CSR initiative in Bukit Awang, PasirPuteh Kelantan in Malaysia. A qualitative research strategy that explores the perspective of social actors that involved in the project and thematic data analysis are undertaken for that purpose. The result from the analysis reveals two main roles played by the government agency in CSR project by the corporation to the community. The roles are as the supporting agency and as leader in the community. These roles have assisted in the implementation of the CSR project with the objectives to develop the community involved.
\end{abstract}

Keywords: corporate social responsibility (CSR), roles of government agency, recipients perspectives analysis, CSR partnership

\section{Introduction}

Corporate Social Responsibility (CSR) has gained prominence globally and has been discussed as one of the avenues for the corporate sector to contribute to the process of developing the community (Ideamudia, 2008; Blowfield, 2007; Muthuri, 2007). According to The World Business Council for Sustainable Development (WBCSD), CSR is defined as the commitment of business to contribute to sustainable economic development, working with employees, their families, the local community and society at large to improve their quality of life (WBCSD, 2002). The roles of corporation in assisting the development of the community have also been recognized in the objectives of the Millenium Development Goals (MDGs) that established the position of corporations as partners in development (WBCSD, 2010). However, they are also critics that the corporation alone is unable to assist community development through their CSR project (Frynas; 2005, Utting; 2005, Fox; 2004). As an organization that's been established for the purpose of maximizing shareholder wealth, business corporations are seen as having lack of social skill in pursuing the effort with social motives particularly in community development (Frynas, 2005; Newell, 2005; Fox, 2004; Davis, 1973). To overcome such constraints, corporations are encouraged to embark into partnership with government agency to effectively implementing CSR programs and initiatives as their CSR strategy particularly for the purpose of development (Seitanidi \& Crane, 2009; Kolk, Tulder \& Kostwinder, 2008; Ideamudia, 2007). This issue has led to the discussion of the roles of the government agency in the CSR project initiatives. This paper will look into the roles played by the government agency in assisting the CSR project implementation by a corporation towards the community in the case study.

\section{The Roles of Government Sector in CSR Project}

At the macro level discussion, government sector is expected to play the roles as the driver of CSR initiatives by the corporation for the benefit of the society (Moon, 2004; Fox, Ward \& Howard, 2002). The expectation of the government sector roles in CSR implementation can also be regarded as reciprocity efforts by the sector towards 
the initiatives of the business corporation in contributing to the development of the community. Thus, the government sectors are expected to provide enabling environment to assist and encourage the business corporation to undertake CSR effort as one of the business strategy in the country. The enabling role plays by the government sector would refer to four key roles that are mandating, facilitating, partnering and endorsing (Fox et al. 2002). However, at the micro level discussion, the roles are reflected in the implementation strategy which is known among others as public-private partnership CSR strategy. The aims of the partnership are to share resources, knowledge and capability between business corporations and the government agency. According to Kolk et al. (2008:267), in the private-public partnership strategy the business corporation would tend to link the CSR project with the core activities in order for the corporation to provide knowledge, expertise and some funding. While the government sector involves would be responsible to reduce the risk of failure of the project through financial support and facilitate to bring the community and companies together to expose the community to the market and network building. By combining organizational resources through partnership strategy, it is hoped that the project would benefit each partner as well as the society at large (Seitanidi \& Crane, 2008).

On the other hand, in the process of developing the community, Community Development Agency (CDA) (1997)observes that the leadership roles are among the factors that need to be given attention. Leaders are performing a variety of tasks that influence, motivate and facilitate others to work together to reach the desired goals in achieving community development. The importance of the leadership roles also being reflected in the Community Development Model developed by ShatarSabran (2003: 139) as one of the important elemens of the process. There are three categories of community leader. The positional leaders are those that have been appointed to hold a certain position in the community where the appointment may either made by the community themselves or by the government of the country. Whereas functional leaders are the ones that being recognized based on their involvement in certain activities but will no longer considered as a leader once the activities end. Lastly, influence behind the scene leader are those that have the reputation and likelihood of giving effect out of those reputations. Furthermore, CDA also identifies three critical factors for a successful leader that are i) the expectations of people and communities ii) perception of what is possible for the leaders and iii) concept and skills of leadership (Shatar, 2004:70).

\section{Case Study: Contract Farming CSR Project}

The CSR initiatives understudied is a chili contract farming project initiated by a multinational corporation which is known as one of the largest food, nutrition, health and wellness company towards the local farmers in the state of Kelantan. The project is implemented through collaboration with the Local Farmers Association (LFA) of Bukit Awang, Pasir Puteh Kelantan. LFA is one of the agencies under the Ministry of Agriculture and Agro based Industry Malaysia which is responsible in enhancing the quality of life of farmers in the country with the support from the Agriculture Department. The project commenced from the year 1996 where the corporation agreed to tie up a contract with LFA to purchase the chili produced by the farmers at Bukit Awang, PasirPuteh Kelantan at a fixed price and a fixed quota.

Starting with the involvement of only 4 farmers during the initial year, the project has grownand managed to get 245 chili farmers that plant chili in 245 acres land in the state of Kelantan particularly in the district of PasirPuteh. As stated in the CSR annual report of the corporation, this project is undertaken to create new income opportunities and also to provide a sustainable source of income for the poor farmers in the local community. It was also reported that on average the farmers has earned net income of US $\$ 365$ per month which is more than double their original income of US\$150 per month from the project, In the year 2005, the project has won the Prime Minister's Award for Corporate Social Responsibility in Malaysia under the category of Socioeconomic Development. To date, the project is still going on in Pasir Puteh Kelantan and a pilot project with a similar contract farming strategy has been implemented in Sarawak replicating the strategy with the cultivation of red rice.

\section{Methodology}

The study was conducted using qualitative methodology based on the interpretive inquiry which put emphasis on the insider interpretation of the social reality (Reevany, Eleesya \& Blaikie, 2006). The insider refers to the social actors that is involved in the CSR project which in this context are the farmers whom are also the beneficiaries or the recipients of the CSR project. Studies on community development field found that, the interpretation of the beneficiaries of the development project would reflect the reality of the project whereas the interpretation of the development actors would normally reflect the ideal roles and their expectation of the project (Akpan, 2008; Newel, 2005). This study regards the recipients of the project as the informants that would reveal the knowledge of the reality understudied regarding the roles played by the LFA as a proxy to the government. Hence, to gain 
the view of the reality of the CSR project pertaining to the roles played by LFA on behalf of the government, in-depth interviews have been conducted with 45 farmers that involved in the project. The data from the interviews were analyzed using thematic analysis method to come out with the themes which reflects the objectives of the study. A thematic analysis method that subscribed to the constant comparative method of analysis has initially identified subthemes before being clustered into themes of the studies that describe the objectives of the research.

\section{The Roles of Local Farmers Association}

The thematic analysis of the study comes up with 9 sub-themes which then being clustered into 2 themes that reflect the roles of LFA. The two themes that describe the roles of the LFA are i) The supporting agency and ii) The leadership roles in the community.

Table 1. The themes of LFA roles in CSR project towards community

\begin{tabular}{llc}
\hline \multicolumn{1}{c}{ Themes } & \multicolumn{1}{c}{ Sub-themes } & No of occurrence \\
\hline $\begin{array}{ll}\text { 1. The supporting agency } \\
\text { (38) }\end{array}$ & 1. As a place of reference & 13 \\
& 2. Offering credit farming & 9 \\
& 3. Arranging for sales, purchasing and financial management & 6 \\
& for farmers & \\
& 4. Encourage farmers to succeed & 6 \\
& 5. Providing equipments and machines & 2 \\
2. Leadership roles & in & 7. Caring executives \\
community (16) & 8. Chairman with high spirit & 2 \\
& 9. A chairman that knew how to motivate & 9 \\
\hline
\end{tabular}

\subsection{The Supporting Agency}

The analysis shows that the first theme that is "The Supporting Agency" emerged from six subthemes that 4 are i) as a place of reference ii) Offering credit farming iii) Arranging for sales, purchase and financial management for farmers iv) Encourage farmers to succeed v) Providing equipments and machines and vi) as intermediary between farmers and corporation.

From the farmers view, LFA is an agency that serves as a place of reference for the farmers. The farmers will refer every problem encountered from every aspect of their day to day life as a farmer to LFA in the process of implementation of the contract farming. One of the farmers narrated that "LFA helps us a lot. They teach us the technique of planting and we refer everything to them. We can ask help from them and they will definitely help us. If we call them today, normally latest by tomorrow they will come to see us. They do many things to enhance our capacity as farmers". Besides as a place of reference LFA also act as financial saviors to the farmers by offering them a short term loan which is termed as credit farming. These credit facilities are used by the farmers for the initial capital needed in embarking into the project. Being farmers with limited financial capability, these credit facilities mean a lot to them. The remark by one of the farmers when narrated about this issue was "LFA gives us credit facilities to start farming. Since we want to start something big (planting at least 1000 chili plants) we need capital to start. We don't have that much. LFA offer us credit and encourage us to start planting".

Not only LFA helps the farmers with their initial capital, LFA also help them in managing the sales of their crops and also managing their return from sales. The farmers would only need to produce the chili crops while the rest of the process of the contract farming transaction would be handled by LFA on behalf of the farmers. According to one of the farmers being interviewed "they (refer to LFA) make it easy for us. They will help us sell our crop to the corporation and they will collect the money for us and deduct the initial credit given to us before handing over the remaining sales return. We can trust them because every transaction has receipts that we can refer to"

The study also reveals that the LFA are seen by the farmers as the catalyst of the project. The farmers realized LFA really want them to succeed in this farming project and would encourage them as much as they can for that purpose. According to one of the farmers in describing what LFA has done to them, he narrated that "We can see 
they are (refer to LFA) very concerned about us. They will not only stay in the office and wait for us to see them. They will come down to the field, monitor us, help us, and visit us so that we keep on with our effort to participate successfully in the project.

In enhancing the efficiency and productivity of the farmers, the association also supplies equipment and machines needed by the farmers for the farming activities. As these machines are expensive to buy, the farmers are seen much appreciated for what they received from the LFA. The farmers that identified this issueregards the equipments and machines as other facilities from LFA that assist them to make their job as farmers easier and faster. Even though in most cases the farmers have to share the machines and equipments with other farmers, they don't find obstacles in doing so. The farmers also reveal that LFA is acting as the intermediary agent between the farmers and the corporation. Most of the communications with the corporation especially on the matter of planting techniques, quality of crops, marketing systems are all done by the LFA on behalf of the community. According to one of the farmers "the corporation does not deal directly with us. Even though they (refer to the corporation) have their manager that monitor the crops that we plant but most of the time he will do the field visit with the LFA and communicate with LFA staff about it. He will tell LFA if it needs to be improved or anything. Later LFA will call us and discuss it with us"

\subsection{The Leadership Roles in Community}

The results of the thematic analysis also show that not only the LFA acted as supporting agency towards the community to ensure their ability to participate in the CSR project, the LFA also play leadership roles in the community. There are three sub-themes that support the theme that are i) Caring executives ii) Chairman with high spirit and iii) Chairman that motivate.

The narratives of the respondents describe the roles of LFA is not only as an organizationthat'sbeen established to help the farmers but at the same time they also reveals the roles played by the executives and chairman of the association. Hence, these roles of the upper level position in LFA portray leadership roles by association. From the narration of the farmers, the most obvious sub-themes that describe the leadership roles are the action of caring executives of the association. The executives refer to assistant chairman and also the plant manager. According to one of the farmers "the executive in LFA (mentioning the name) is very caring for us. It is easy for us to discuss anything with him. He will listen to our problems and help us as much as he can. He has been here with us more than 10 years! In fact there were incidences that some of us were out of money during the early years of our involvement with the project. We mention this to him. He lends us his pocket money and only ask us to pay later when we get the return from our crops. We are very indebted to him. He really cares for us and will not let us down".

The farmers also reveal about the leadership styles that the chairman of LFA towards them. Even though during the time of the interview the chairman is already retired, the farmers still regard him as their leader. He is known with his high spirit that upliftedthe spirit of the farmers and he is also known with his motivation strategy that influenced the farmers to geared their effort to become successful in their farming project. Among the narration that describes the leadership style of the LFA chairman are:

As far as I can remember, our chairman of LFA is a very confident leader. He really manages this project full heartedly and very confident that this project would

We are afraid of him (giggling) but at the same time we respected him. He will always in the field early in the morning after dawn. He is strict but at the same he knows how to tackle us. When we did the best, he always gives us a thumb up. He always said to us, I don't need the money because the government will pay me my salary but you people need it, so do the best to earn it.

Those remarks of the farmers towards the chairman have contributed to the emergence of sub-themes i) chairman with high spirit and ii) chairman that motivate. These sub-themes have been grouped together and show the leadership roles theme of the study.

\section{Discussion}

The analysis of the recipients' perspectives on the roles LFA reflect the roles played by the government agency in assisting the successfulness of the CSR initiatives towards the farmers' community. The study has shown that the government agency is playing important roles in the implementation of the CSR project. The role as the supporting agency by LFA reveals by the community reflects thefulfillness of enabling environment practiced by the sector as expected at the macro level perspectives as discussed by Moon (2004) and Fox et al. (2002). The enabling environment reveals by the emerging themes of the study referred to the practicality of the implementation process that includes social and financial supports provided by the sectors to assist the 
community and to ensure the ability of the CSR project being implemented in the community. The roles indicate the ability of the government to work closely with the community and to fulfill their roles in enhancing the capacity of the community to participate in the project. At the same time, coherent with the key factors needed in developing the community, the government agency understudied has undertaken leadership roles that are expected by the community. The ability to motivate and act as what is expected of the community has made the agency able to capture the attention of the community to reflect themselves and work on the effort to develop themselves through the CSR project.This study has also indicated that the critical factor of successful leadership as being discussed by CDA has been fulfilled by the LFA and its personnel.This finding reveals the local context of leadership quality expected by the community in assisting and creating an enabling environment for community development. At the same time, the skill possessed by the chairman of LFA in motivating the farmers also shows a critical factor of successful leadership as what's being referred by CDA as a concept and leadership factors.

\section{Conclusion}

The CSR project that principally initiated by the business sectors are encouraged to be implemented with the involvement of the government agency to ensure its effectiveness in benefiting the community. However, the roles of government agency cannot be limited on the macro level involvement but need to be bogged down to the practicality of the implementation of the initiatives. Thus, the enabling environment expected from the government sector need to be continuously implemented at the micro level with the supporting roles by the government agency involved. Additional to it, the leadership roles need to be equally embedded together with supporting effort towards the community to assist in their participating capability towards the project. Hence, even though CSR initiatives are globally known as the prominent effort by the business corporation towards society, concerns on its practical implementation need to be shared with equal effort through collaboration with the government agencywhom are responsible in enhancing the development of the community. However, to shed more light on the roles of the two sectors in the collaborative effort, it would also be interesting to further explore the actual role plays by the business corporation to ensure the practicality and the successfulness of the CSR project implementation in the community.

\section{References}

Blowfield, M. (2007). Reasons to be cheerful? What we know about CSR's impact. Third World Quarterly, 28(4), 683-695. http://dx.doi.org/10.1080/01436590701336523

Bustami, R., Nasruddin, E., \& Blaikie, N. (2004). Lima Falsafah Penyelidikan Paradigmadan Strategi Penyelidikanuntuk Sains Sosialdan Pengurusan. Pulau Pinang, Malaysia: Knowledge Craftsmen.

Davis, K. (1973). The case for and against business assumption of social responsibilities. Academy of Management Journal, 312-322. http://dx.doi.org/10.2307/255331

Fox, T. (2004). Corporate Social Responsibility and Development: In quest of an agenda. Development, 47(3), 29-36. http://dx.doi.org/10.1057/palgrave.development.1100064

Fox, T., Ward, H., \& Howard, B. (2002). Public sector roles in strengthening corporate social responsibility: a baseline study. World Bank Washington, DC.

Frynas, J. (2005). The false developmental promise of Corporate Social Responsibility: evidence from multinational oil companies. International Affairs, $81(3), \quad$ 581-598. http://dx.doi.org/10.1111/j.1468-2346.2005.00470.x

Ideamudia, U. (2008). Conceptualizing the CSR and development debate: Bridging existing analytical gaps. Journal of Corporate Citizenship, 29(Spring), 91-110.

Kolk, A., Van Tulder, R., \& Kostwinder, E. (2008). Business and partnerships for development. European Management Journal, 26(4), 262-273. http://dx.doi.org/10.1016/j.emj.2008.01.007

Moon, J. (2004). Government as a driver of corporate social responsibility. ICCSR Research Paper Series, (20), 6-7.

Muthuri, J. N. (2007). Participation and accountability in corporate community involvement programme: a research agenda. Community Development Journal, 1-17.

Newell, P. (2005). Citizenship, accountability and community: the limit of the CSR agenda. International Affairs, 81(3), 541-557. http://dx.doi.org/10.1111/j.1468-2346.2005.00468.x

Sabran, M. S. (2003). Model pembangunankomuniti. Pertanika Journal Social Science \& Humanities, 11(2), 
$135-145$.

Sabran, M. S. (2004). Community development model and productivity enhancement. DalamDaniSalleh. (pnyt). Pembangunan Komuniti: Dasar, Konsep, StrategidanIsu di Malaysia. Sintok:Universiti Utara Malaysia.

Seitanidi, M. M., \& Crane, A. (2009). Implementing CSR through partnerships: Understanding the selection, design and institutionalisation of nonprofit-business partnerships. Journal of business ethics, 85, 413-429. http://dx.doi.org/10.1007/s10551-008-9743-y

Smith, N. C. (2003). Corporate Social responsibility: Not Whether, But How?Center for Marketing Working paper. London Business School: London. Retrieved April 27, 2012, from http://www.london.edu/facultyandresearch/research/docs/03-701.pdf

Stirling, J. A. (2001). Thematic network: an analytic tool for qualitative research. Qualitative Research, 1(3), 385-405. http://dx.doi.org/10.1177/146879410100100307

Utting, P. (2005). Corporate responsibility and the movement of business. Development in Practice, 15(3-4), 375-388. http://dx.doi.org/10.1080/09614520500075797

World Business Council for Sustainable Development (WBCSD). (2002). The Business Case for Sustainable Development. Making a Difference towards Johanesburg. Retrieved April 15, 2007, from http://www.wbcsd.org

World Business Council for Sustainable Development (WBCSD). (2010). Accelerating Progress towards the Millenium Development Goals Through Inclusive Business. Retrieved October 29, 2010, from http://www.wbcsd.org 